FACTA UNIVERSITATIS

Series: Teaching, Learning and Teacher Education Vol. 4, № 2, 2020, pp. 147 - 156

https://doi.org/10.22190/FUTLTE2002147M

Review article

\title{
ICT IN TEACHING - ONCE A CHOICE, NOW A NECESSITY
}

\author{
UDC 371.3:004.032.6; 371.134
}

\section{Aleksandra Milanović, Biljana Novković Cvetković}

\author{
Pedagogical Faculty in Vranje, University of Niš, Serbia
}

\begin{abstract}
The usage of ICT in the teaching process was a recommendation and an opportunity to innovate and actualize it until only a few months ago. The inevitable change caused by the unexpected circumstances triggered by Covid-19 brought all teachers into a situation where there was no room for consideration and no option to avoid the use of modern technology for learning and teaching purposes. Taking into account current situation that indicates the need for integration ICT into the teaching process, the aim of this paper was to analyze the relevant research, to point out the inevitability of providing additional support to teachers for the use of ICT in teaching. Accordingly, the research objectives was: pedagogical significance and contribution of ICT integration in the teaching process, the importance of the role of teachers in the process of ICT integration in teaching, as well as potential obstacles and difficulties that teachers may face in using ICT in teaching process. The obtained results can contribute to a more comprehensive view of the problems that teachers could face in the implementation of ICT in teaching, which would allow the determination of directions that would affect changes in their opinion related to acceptance and promotion of learning in ICT environment, as well as advantages to innovate teaching process by using ICT in teaching.
\end{abstract}

Key words: modern technology, pedagogic significance, teacher, potential limitations

\section{INTRODUCTION}

The introduction of ICT (information and communications technology) into the teaching process is no longer a recommendation, an idea, a way to innovate teaching; on the contrary, it is now a necessity and a precedent when it comes to the teaching process at the time that has be fallen us. The unexpected situation caused by the COVID-19 virus, a world-wide problem, significantly affected the teaching process.

Received September 11, 2020/Accepted November 27, 2020

Corresponding author: Aleksandra Milanović

Pedagogical Faculty in Vranje, University of Niš, Partizanska 14, 17500 Vranje, Serbia

Phone: +381 17431960 •E-mail: aleksandram@pfvr.ni.ac.rs 
ICT is no longer a learning tool resorted to and used by older high school students and university students. Technology has become equally important and significant when it comes to the process of learning and teaching in the first cycle of education - from the first to the fourth grade. The teaching process depends on the level of digital competence of teachers. Only a teacher who is trained to apply ICT for educational purposes can manage the teaching process, as evidenced by the period starting from March 16, 2020, when schools were closed due to exceptional and unforeseen circumstances and when online learning and teaching started to be used. The prerequisite to finish the 2019/2020 school year in the Republic of Serbia, as well as everywhere in the world, was to embrace and integrate ICT in the teaching process. Although for decades it was written and talked about the need, importance and possibilities of using ICT for educational purposes, we had the opportunity to use everything in practice and see all of the above. In this situation, knowledge from this subject area was not enough to carry out the teaching process.

This theoretical research is another in a series with the intention to shed light on and bring closer the current issue, that is, the issue of integrating ICT into the teaching process. By clarifying the process of integrating ICT into the teaching process, with the emphasis on pedagogic significance and impact to the overall teaching process, and by explaining the teachers' role and importance for the efficient use of technology with the emphasis on teacher competencies that have been highlighted as important to studying this issue, so the emphasis is on digital competence and IT and information skills of teachers. That is why it is important to point out to the difficulties encountered when using ICT in teaching, obstacles that hinder the effective use of ICT, but also the undesirable effect that this way of learning can have on students, all with the intention of helping teachers and pointing out potential dangers that may arise now that ICT is used on a daily basis.

\section{INTEGRATING ICT IN TEACHING - PEDAGOGIC SIGNIFICANCE AND CONTRIBUTION}

The efficient use of ICT implies the transfer and use of all types of information, with an emphasis on the role of communication and the integration of telecommunication, computer technology and audio-visual systems, which allow users to access, store, transfer and use information (Čelebić \& Rendulić 2011; Carnoy, 2005). Information and communications technology is of key importance at all levels of the education system. In each phase of cognitive activity, research and practical application in all branches of knowledge, ICT is also used as a tool and object of knowledge. Consequently, ICT innovations not only provide revolutionary development, but also have a direct impact on scientific and technological progress in all areas of society. Therefore, information and communications technology involves a group of innovative technologies used for the rapid accumulation of intellectual and economic potential of strategic resources, ensuring sustainable development of societies that trigger innovation in teaching and also have made a drastic change when compared to the old teaching and learning paradigm (Bilialova, 2017, p. 176; Damodharan \& Rengarajan, 2007). The goal of integrating ICT in schools is to make the learning process efficient, attractive and current (Haji, Moulayonge, \& Park, 2017), which has brought about radical changes in the education system and facilitates their acceptance, makes teaching more robust and connects it with the world (Ubogu \& Veronica, 2020).

Information and communications technology have been identified as a catalyst for educational change, change in work conditions, access and information handling and exchange, innovation of teaching methods and approaches to learning, and for a change 
in the way research is conducted (Mikre, 2011). As such, they offer a variety of technological equipment and resources used to communicate, generate, distribute, collect and store information. It consists of hardware, software networks and media (Olaore, 2014; Sarnar, 2012) which leads to difficulties when it comes to defining ICT (Gill, 2017) due to its complexity but also the rapid development of modern technology.

The most commonly used ICT tools for teaching purposes are the Internet, E-mail and word processing (Tezci, 2009). The Internet is used to quickly and easily access information, helps to understand certain information, facilitates regular communication and data exchange, development of new concepts, structuring and analysis of information, increases the degree of information storage and speeds up the learning process (Osadichyi, 2019).

Technology in education should not be considered as a replacement for face-to-face instruction but rather as a support to "attain objectives that have not been attained efficiently otherwise: expanding access, promoting equality, improving the internal efficiency of educational systems, enhancing the quality of education, and preparing new and old generations for a technology-driven market place" (Haddad \& Jurich 2002, p. 47). Hughes (1998, according to Krabonja and Šverc, 2019) and Puentdura (2014, according to ibid) have made a significant impact in regard to integrating ICT into the teaching process, which actually affects the decision-making by teachers on the integration of modern technology into the teaching process.

The first model developed by Hughes, R.A.T. model (Replacement Amplification and Transformation) served as the basis for further development and upgrade of S.A.M.R. model (Substitution, Augmentation, Modification and Redefinition) developed by Puentdura. These authors (Ibid, 2019), started from the position that the introduction of technology into the teaching process contributes to the achievement of goals set, and made a comparison in the way given in Table 1.

Table 1 Comparison of the R.A.T. and S.A.M.R. model

\begin{tabular}{|c|c|}
\hline R.A.T. MODEL & S.A.M.R. MODEL \\
\hline REDEFINITION & SUBSTITUTION \\
\hline $\begin{array}{l}\text { Technology serves as a digital tool to achieve } \\
\text { learning outcomes. Teaching methods, learning } \\
\text { processes and outcomes remain the same. }\end{array}$ & $\begin{array}{l}\text { Technology understood as a substitution without } \\
\text { significant improvement and functional changes } \\
\text { to the teaching process. }\end{array}$ \\
\hline AMPLIFICATON & AUGMENTATION \\
\hline $\begin{array}{l}\text { The focus is on the application of technology that } \\
\text { amplifies existing teaching methods, processes and } \\
\text { learning outcomes. The main outcome is the } \\
\text { increase of success and productivity. }\end{array}$ & $\begin{array}{l}\text { Technology understood as a replacement with } \\
\text { functional improvement } \\
\text { (example: technology enables content sharing, } \\
\text { commenting and correction) }\end{array}$ \\
\hline TRANSFORMATION & MODIFICATION \\
\hline \multirow[t]{3}{*}{$\begin{array}{l}\text { The use of technology transforms the teaching } \\
\text { methods, the learning process and the subject, } \\
\text { which further reorganizes student learning process }\end{array}$} & $\begin{array}{l}\text { Technology enables significant change of tasks } \\
\text { (example: text processing can be replaced by blog } \\
\text { writing and the possibility of publishing } \\
\text { multimodal text) }\end{array}$ \\
\hline & REDEFINITION \\
\hline & $\begin{array}{l}\text { Creating tasks which cannot be solved without } \\
\text { the use of technology (example: writing is } \\
\text { transformed into digital storytelling) }\end{array}$ \\
\hline
\end{tabular}

The above table can serve as a guideline for teachers when it comes to integrating information and communications technology into the teaching process. Guided by it, the 
teacher can observe the level of ICT integration, or plan and anticipate the next step in this process.

Integrating ICT into the teaching process has pedagogical aspects that the author (Tunio, 2002, according to Mikre, 2011) explained through 5 segments of learning: active learning, cooperative or collaborative learning, integrative and evaluative learning. Active learning is ICT-supported learning, it applies tools to test, calculate and analyze information to enable student assessment via the learning platform. In this case, ICT makes learning less abstract and more relevant to real life situations. Student engagement increases, the possibility of choosing the content to be studied is ensured, as well as the possibility of choosing the time when students will learn. The second segment, collaborative learning through ICT, encourages interaction among students, provides the opportunity to collaborate with peers even though they are not in close proximity, and provides the opportunity to simultaneously involve peers, teachers and other professionals from different fields. Creative learning supports innovative, creative work and the use of existing information. Integrative learning, as the fourth segment, promotes the thematic integrative approach to teaching and learning through ICT. Unlike traditional learning, it eliminates differences and division between different disciplines, theory and practice. And lastly, evaluative learning is aimed at diagnosing and predicting the expected results of learning, research and discovery with the help of ICT. What we can add to the definitions provided by the above-mentioned author is distance learning. This type of learning is impossible to be organized and carried out in any other form except with the help of ICT. The advantages of this type of learning highlight the importance of using ICT, which include no tuition cost, the ability to choose the way and pace of learning based on individual abilities, no limitation from the aspect of regional differences, the use of various digital learning tools and the improvement of digital competences of both teachers and students (Ismailova \& Ergshew, 2019).

The benefits and impacts of using ICT in the teaching process are numerous, and it is possible to see them from the perspective of teachers, students, school and society as a whole. The overall benefit includes the strengthening of interaction and information sharing among students, the use of various forms of e-learning and the need to improve the English language knowledge, both by teachers and students (Ramya \& Clement, 2020; Gizaw \& Tessema, 2020; Kostović-Vranješ and Tomić, 2014). Looking at the teaching process and the importance of ICT, we can synthesize the positive impacts that the authors (Sarnar, 2012; Mikre, 2011) singled out:

1. It offers an opportunity for teaching to be student-cantered.

2. Improves the opportunity for communication and collaboration among students themselves, as well as teachers and students.

3. It enables students to acquire better, professional and working skills.

4. It increases student enthusiasm for learning.

5. It prepares students for real life.

6. It facilitates students' access to online teaching materials.

7. Provides the ability to use a variety of digital resources for learning purposes.

8. Creates an open learning environment that allows information and materials to be stored and used as many times as needed.

The use and importance of ICT in teaching has resulted in a new learning paradigm, in where the role of teaching factors has changed. Namely, the teacher is not the only source of knowledge, they slowly transform their role of teacher into the role of a guide during the learning process. In addition to being taught the necessary knowledge and 
skills, the student is instructed, guided and directed on how to use learning resources that are found outside the classroom. The student becomes more and more active, while the learning content is transformed, changed and innovated with the use of modern technology. In regard to these changes, the authors (Damodharan, \& Rengarajan, 2007) point out that the new way of learning primarily focuses on students, not teachers or learning content. Modern technology and the Internet enable students to work, learn and research independently. These improve and modernize the teaching process, making it more efficient by introducing more sensory components into the information flow (Vilotijević \& Mandić, 2016; Vilotijević, 2007). Educational goals must be aligned with information technology (National Education Council, 2013, p. 4).

\section{Teacher as a Factor AfFecting ICT Integration in the Teaching Process}

For the purposes of integrating ICT into the teaching process, it is necessary to classify teacher competencies, which differ from the traditional teaching competencies the possession of which is implied. Krabonja and Šverc (2019) classify teaching competencies into 5 categories:

1. Good mastery of skills, knowledge and abilities needed for the $21^{\text {st }}$ century,

2. Knowledge of the subject content to a level that will enable them to develop competencies to select the content that may be significant at a given time,

3. Ability to plan and collaborate with colleagues in order to enable synergy of performance and avoid oversaturation in certain areas of learning

4. Pedagogical and didactic knowledge that will enable continuous monitoring and the evaluation of results

5. Ability to use modern technology, search and evaluate applications used for the implementation of activities to achieve general and specific objectives of a subject.

Information literacy is a prerequisite for the efficient usage of information and recognizing the need for it, having knowledge of how to find, evaluate and use information in order to solve problems. An information-literate person knows how to learn, organize knowledge, find and use information in the right way (Kostović-Vranješ \& Tomić, 2014). Acquisition of information-professional competence of future teachers mostly depends on the information literacy of the teachers themselves. ICT-based teaching expands the range of cognitive tasks, enables the transition to systematic management of teaching activity, changes its structure and dynamics. In order to achieve this, it is necessary to rearrange the operational-technical aspect of teaching, change the spatial and temporal boundaries of interaction, and form a self-regulation system in working with information technologies. Two types of competencies have been singled out as the most important ones for the integration of modern technology into the teaching process:

1. Basic computer and information literacy (competence of teachers for multimedia management, browsing skills).

2. Multimedia didactic competencies (Vrkić-Dimić, 2014).

Today's teacher has the task to help students solve "modern" problems: too much available information, finding reliable data, protection of data and identity in the digital space, accelerating innovation, legal and ethical standards in the information society (Osadichyi, 2019). The use of ICT in teaching depends primarily on the teacher (KostovićVranješ and Tomić, 2014). Teacher is a factor which the way, level and efficiency of 
innovating the teaching process depends on. Level of teachers' knowledge about ICT, level of digital skills, frequency of using ICT for educational purposes, teachers' attitudes towards the use of computers and the Internet as teaching media, self-confidence, self-image, pedagogical approach to students, awareness of changes that occur due to the use of ICT for educational purposes are features that describe the level and manner of ICT usage for educational purposes (Osadichyi, 2019; Afshari, et all 2009). However, the manner and frequency of using ICT in teaching are also conditioned by the school policy or national policy, availability and access to funds, support from school management, and opportunities for learning, and improving the use of ICT for educational purposes (Mumtaz, 2000).

Acquiring knowledge and skills in the field of ICT is one of the preconditions for social inclusion in modern society. ICT should be integrated into the education system in order to achieve quality education for all. Previous practical experiences, pedagogical and especially psychological knowledge, show that in addition to broader and narrower social factors, the characteristics of teachers also significantly influence the introduction of ICT in schools.

\section{DIFFICULTIES THAT MAY HINDER THE INTEGRATION OF ICT IN TEACHING}

Conservatism and traditionalism of teachers who are afraid to apply innovation in the teaching process is the main obstacle to the introduction of information technology into the teaching and learning process (Novković Cvetković \& Stanojević, 2017). The most common reasons why teacher avoid to integrate ICT in the teaching process are mistrust and low level of teacher competence, and teacher's lack of training to use ICT (Haji, et all 2017). Teachers are sometimes not interested in applying new ways of teaching and learning and prefer to remain consistent with what they have been using for years - the traditional way of teaching. Nowadays, however, ICT offers a whole range of opportunities that can contribute to increasing teacher interest. There are teachers who have actually implemented information and communications technology in their teaching process, but not in an adequate way. Namely, many teachers do not know how to use the potentials of ICT in their teaching, or ICT is used the wrong way. Ways of reacting, when it comes to changes in teaching work, Suzić (2010) explains with three possibilities: jumping into changes without many questions, hesitation and opposition to changes (p. 220). When it comes to changes in teaching methods states that there can be three types of reactions: embracing change without many questions, hesitation and opposition to change.

There are three factors affecting the integration of ICT in teaching - teacher, student and technology. Teachers can be hindered by a negative attitude towards the use of ICT with regard to the process of integrating it into the teaching process; lack of knowledge about the benefits that technology can provide; insufficient help and support from the school administration, inconsistency between ICT integration and professional development of teachers; additional efforts to find and successfully align course objectives with the use of ICT in the process the objectives' realization; and the importance of knowing a foreign language, most often English (Mikre, 2011).

A difficulty that occurs when it comes to integrating ICT into teaching is equating it with basic computer literacy. The authors Vrkić-Dimić (2014) state that the effective integration of ICT involves learning and teaching that takes place by using advanced forms of application of technology in teaching. Proper use of ICT brings learning to a higher level, 
enables higher levels of thinking and provides an opportunity to construct new knowledge in the information environment. In addition to the difficulties associated with the teacher as a primary factor in the teaching process, and thus the most important factor affecting the process of ICT integration into teaching, it is necessary to highlight the conditions that depend on the school, and largely determine and influence the application of modern technologies for teaching purposes.

These are:

1. Sufficient access to digital technology and the Internet in the classroom,

2. Teachers and students must have access to high-quality, meaningful and culturally appropriate content,

3. Teachers must be prepared to use digital tools and resources to assist the student during learning (Ratheeswari, 2018).

As for the limitations that should be kept in mind, those related to students are as follows:

1. Limiting student imagination,

2. Limiting critical thinking and analytical skills,

3. Superficial understanding of information,

4. Physical side effects (Poor vision, bad posture),

5. Possibly easy disruption of the learning process to visit undesirable websites,

6. Neglecting other learning resources that are not connected to the Internet and the computer,

7. Students do not engage in more detailed analysis but most often rely on presentations and content downloads from the Internet,

8. Less opportunity to use and develop oral skills and handwriting,

9. This type of learning through ICT represents an additional effort and burden for weaker students as they need constant help (Mikre, 2011).

Teachers should keep in mind these difficulties and obstacles or even negative impacts on students. Connecting ICT with the subject content requires teachers to plan and organize ICT-based lessons in advance in order to prevent potential issues, which is another obligation and task for teachers. Therefore, although very useful, and in some situations necessary and inevitable, the application of modern technology is certainly a segment of modern teaching that requires caution and skill.

\section{CONCLUSION}

Modern society is characterized by the informatization of all areas of human life and work. The explosion of new knowledge is the characteristic of the information society where information has become the primary value in which the archiving, processing and transfer of information is based on modern technology and methods of the information era (Molnár, 2014, p. 421; Mandić, 2003). The main driver of the development of the information society (Molnár, 2014, p. 421) is computer technology and the rapid development of telecommunication. Nowadays, all scientific, technological and social changes occur rapidly (Kostović-Vranješ, et all, 2015, p. 15), and educational systems must adapt to the information age. Teachers used ICT only when it fitted their traditional way of teaching. In the beginning, information and communications technology was used only for designing and preparing the teaching process, but with the more frequent use of modern technology 
in teaching, there has been a change in the way of working, learning, teaching and the overall organization of the teaching process. This can be understood as the reason for modernization of professional development program (Kostović-Vranješ, et all, 2015; Kostović-Vranješ \& Tomić, 2014). Starting from the assumption that teachers use ICT resources only to prepare teaching materials, the authors (Kostović-Vranješ \& Tomić, 2014) came to the finding that teachers often resort to using existing teaching materials, which they attributed to teachers' lack of computer skills. The circumstances that are important even now for the integration of ICT into the teaching process, which the authors (Afshari, et all, 2009) singled out, and which can help us today with integration but also with the evaluation of teaching through modern technology are investments in the capacity of teachers to use ICT in education, constant exchange of knowledge with colleagues, support from school management and administrators, as well as strengthening the school infrastructure (Sahin, 2014). Accepting and promoting computer-based work and learning, consistent use of computers to prepare and implement the teaching process, additional efforts to teach students aspects of using and learning with computers (Mumtaz, 2000), influencing student awareness of digital literacy are important for integrating ICT in teaching. A positive example of supporting the integration of ICT in teaching are the results of the research conducted in 2016 (Wanjala, 2016), which bring closer the way in which teachers should be helped. Namely, in Kenya, many efforts and resources have been invested to improve the competence of teachers for the efficient use of ICT, the Ministry of Education of this country has developed a serious approach and policy for ICT in education, while schools as independent units organize internal training and courses for employed teachers. Namely, in Kenya, many efforts and resources have been invested to improve teacher competencies for the efficient use of ICT, and the Ministry of Education of this country has developed a serious approach and policy for the usage of ICT in education, while schools as independent units organize internal training and courses for teachers.

The need for teachers to feel the need to use ICT in education and their willingness to use ICT as factors to consider, the authors Ward \& Parr (2010) see as a driver to accept and effectively use technology for educational purposes. However, we are now in a situation that has shifted our horizons, ignored personal positive and negative attitudes and experiences when it comes to the usage of ICT for teaching purposes. Therefore previous analysis could contribute in solving teacher doubts about the implementation of ICT in teaching, which could allow the determination of directions that would affect changes in their opinion related to acceptance and promotion of learning in ICT environment, as well as advantages to innovate teaching process by using ICT in teaching.

\section{REFERENCES}

Afshari, M., Bakar, K. A., Luan, W. S., Samah, B. A., \& Fooi, F. S. (2009). Factors affecting teachers' use of information and communication technology. Online Submission, 2(1), 77-104. Accessed February 2020, Availlable at: https://files.eric.ed.gov/fulltext/ED524156.pdf

Bilyalova, A. (2017). ICT in Teaching a Foreign Language in High School. Procedia-Social and Behavioral Sciences, 237, 175-181. https://doi.org/10.1016/j.sbspro.2017.02.060

Carnoy, M. (2005). ICT in Education: Possibilities and Challenges. Universitat Oberta de Catalunya.

http://www.uoc.edu/inaugural04/eng/carnoy1004.pdf

Čelebić, G., i Rendulić, D. I. (2011). Osnovni pojmovi informacijske i komunikacijske tehnologije. U ITdesk.infoprojekt računalne e-edukacije sa slobodnim pristupom - Priručnik za digitalnu pismenost. Zagreb: Otvoreno društvo za razmjenu ideja (ODRAZI). Retrieved September 2015, from: http://www.itdesk.info/prirucnik osnovni_pojmovi_informacijske_tehnologije.pdf 
Damodharan, V. S., \& Rengarajan, V. (2007). Innovative methods of teaching. In Learning Technologies and Mathematics, Middle East Conference (pp. 1-16). Muscat, Oman: Sultan Qaboos University. https://www.math. arizona.edu/ atpmena/conference/proceedings/Damodharan_Innovative_Methods.pdf

Gill, K., A. (2017). Role of ICT in effective curriculum transaction and evaluation. IJAR, 3(1), 432-437.

Gizaw, M. E., \& Tessema, G. W. (2020). Role of information and communication technologies in educational systems: a systematic review. International Journal, 6(7), 272-282. http://dx.doi.org/10.18203/issn.24542156.IntJSciRep20202644

Haddad, D. W., \& Jurich, S. (2002). ICT for education: prerequisites and constraints. In W. D. Haddad and A. Draxler (Eds.), Technologies for Education: Potential, Parameters and Prospects (pp. 42-57). Washington, DC: UNESCO-Academic for Educational Development.

Haji, S. A., Moluayonge, G. E., \& Park, I. (2017). Teachers' Use of Information and Communications Technology in Education: Cameroon Secondary Schools Perspectives. Turkish Online Journal of Educational TechnologyTOJET, 16(3), 147-153.

Ismailova, Z., \& Ergashev, B. (2019). New information and communication technologies in education system. In E3S Web of Conferences, 135 (pp. 1-8), EDP Sciences. https://doi.org/10.1051/e3sconf/201913504077

Kostović-Vranješ, V., Bulić, M., i Novoselić, D. (2015). Kompetencije učitelja biologije za primjenu informacijskokomunikacijskih tehnologija u nastavnom procesu, Zbornik radova Filozofskog fakulteta, 6(7), Split, 15-26.

Kostović-Vranješ, V., \& Tomić, N. (2014). Training Teachers for the use of Information Communication Technology in Science. Školski vjesnik, 23, 287-307.

Mandić, D. (2003). Didaktičko-informatičke inovacije u obrazovanju. Beograd: Medigraf.

Mikre, F. (2011). The roles of information communication technologies in education: Review article with emphasis to the computer and internet. Ethiopian Journal of Education and Sciences, 6(2), 109-126. http://dx.doi.org/10.6007/IJARPED/v3-i2/919

Molnár, G. (2014). Modern ICT based teaching and learning support systems and solutions in higher education practice. In: 10th International Scientific Conference on Distance Learning in Applied Informatics (pp. 421-430). Praha: Wolters Kluwer Law and Business.

Mumtaz, S. (2000). Factors Affecting Teachers Use of Information and Communications Technology: A review of the literature. In: Journal of Information Technology for Teacher Education, 9(3), 319-342. https://doi.org/10.1080/14759390000200096

Nacionalni prosvetni savet (2013). Smernice za unapređenje IKT u obrazovanju. https://mtt.gov.rs/vesti/ usvojene-smernice-za-unapredjenje-uloge-ikt-u-obrazovanju/?0=lat

Olaore, B. I. (2014). The impacts (positive and negative) of ICT on education in Nigeria. Developing Country Studies, 4(23), 154-156.

Osadchyi, V. (2019). Modern information and communication technologies for the professional training of future teachers. Education: Modern Discourses, 2, 171-177. https://doi.org/10.32405/2617-3107-2019-1-20

Ramya, D., \& Clement, R. S. A. (2020). Integration of Information Communication and Technology (ICT) tools in English Language Teaching (ELT) from Teacher's Perspective. International Journal of Applied Engineering Research, 15(2), 108-110.

Ratheeswari, K. (2018). Information communication technology in education. Journal of Applied and Advanced Research, 3(1), 45-S47. http://dx.doi.org/10.21839/jaar.2018.v3iS1.169

Sahin, A. (2014). The Role of Information and Communication Technologies in Schools: Perspectives of Teachers. International Journal of Academic Research in Progressive Education and Development, Human Resource Management Academic Research Society, International Journal of Academic Research in Progressive Education and Development, 3(2), 112-124. http://dx.doi.org/10.6007/IJARPED/v3-i2/919

Sarkar, S. (2012). The role of information and communication technology (ICT) in higher education for the $21 \mathrm{st}$ century. Science, 1(1), 30-41. https://doi.org/10.1016/j.sbspro.2014.09.199

Suzić, N. (2010). Stare osobine i nove uloge nastavnika, Godišnjak SAO, 215-230.

Tezci, E. (2009). Teachers' effect on ICT use in education: The Turkey sample. Procedia-Social and Behavioral Sciences, 1(1), 1285-1294. https://doi.org/10.1016/j.sbspro.2009.01.228

Vičič Krabonja, M., i Šverc, M. (2019). Znamo li koristiti IKT u svrhu podrške uvođenju inovativnog okružja za učenje? Politehnika: Casopis za tehnički odgoj i obrazovanje, 3(2), 7-17.

Vilotijević, M., i Mandić D. (2016). Informatičko-razvijajuća nastava u efikasnoj školi. Beograd: Srpska akademija obrazovanja i Učiteljski fakultet u Beogradu,

Vilotijević, M. (2007). Didaktika III. Beograd: Školska knjiga.

Vrkić Dimić, J. (2013). Kompetencije učenika i nastavnika za 21. stoljeće. Acta Iadertina, 10(1), 49-61.

Wanjala, M. (2016). Information Communication Technology Pedagogical Integration in Mathematics Instruction among Teachers in Secondary Schools in Kenya. Journal of Education and Practice, 7(2), 66-73.

Ward, L., \& Judy, P. M. (2010). Revisiting and reframing use: Implications for the integration of ICT. Computers and Education, 54 (1), 113-122. https://doi.org/10.1016/j.compedu.2009.07.011 


\section{IKT U NASTAVI - NEKADA IZBOR SADA NEMINOVNOST}

Primena IKT u nastavnom procesu do pre samo par meseci bila je preporuka, mogućnost inoviranja $i$ aktuelizovanja istog. Neizbežna promena nastala pod neočekivanim okolnostima izazvanih Covidom19, dovela je sve nastavnike u situaciju u kojoj nije bilo mesta razmatranju $i$ mogućnostima za izbegavanje korišćenja savremenih tehnologija za potrebe učenja i podučavanja. Imajući u vidu novonastalu situaciju koja ukazuje na potrebu integrisanja IKT u nastavni proces, cilj ovog rada bio je da analizom relevantnih istraživanja ukažemo na neminovnost pružanja dodatne podrške nastavnicima za korišćenje IKT u nastavi. U skladu sa tim, u radu su ispitivani: pedagoški značaj $i$ doprinos integrisanja IKT u nastavni proces, značaj uloge nastavnika u porocesu integrisanja IKT u nastavi, kao i potencijalne prepreke i teškoće sa kojima se nastavnici mogu suočiti korišćenjem IKT u nastavi. Dobijeni rezultati mogu doprineti celovitijem sagledavanju problema sa kojima se nastavnici suočavaju u implementaciji IKT u nastavi što bi omogućilo određivanje pravaca delovanja koji bi uticali na promene u njihovom ponašanju koje se odnose na prihvatanje i promovisanje rada i učenja u IKT okruženju, kao i prednosti inoviranja nastavnog procesa korišćenjem IKT u nastavi.

Ključne reči: savremena tehnologija, pedagoški značaj, nastavnik, potencijalna ograničenja 